The Journal of Agricultural Science

cambridge.org/ags

\section{Animal Research Paper}

Cite this article: Silva GP, Fialho CA, Carvalho LR, Fonseca L, Carvalho PCF, Bremm C, Da Silva SC (2018). Sward structure and shortterm herbage intake in Arachis pintoi cv. Belmonte subjected to varying intensities of grazing. The Journal of Agricultural Science 156, 92-99. https://doi.org/10.1017/ S0021859617000855

Received: 28 July 2017

Revised: 3 November 2017

Accepted: 20 November 2017

First published online: 19 December 2017

Key words:

Continuous stocking management; forage peanut; intake rate; legumes; sward structure

Author for correspondence:

G. P. Silva, E-mail: guilhermeps@usp.br

\section{Sward structure and short-term herbage intake in Arachis pintoi cv. Belmonte subjected to varying intensities of grazing}

\author{
G. P. Silva ${ }^{1}$, C. A. Fialho ${ }^{2}$, L. R. Carvalho ${ }^{1}$, L. Fonseca ${ }^{3}$, P. C. F. Carvalho ${ }^{4}$, \\ C. Bremm ${ }^{5}$ and S. C. Da Silva ${ }^{1}$
}

${ }^{1}$ Animal Science Department, University of São Paulo, E.S.A. 'Luiz de Queiroz', Av. Pádua Dias, 11, CEP 13418-900, Piracicaba, SP, Brazil; ' ${ }^{2}$ Department of Animal Nutrition and Breeding, São Paulo State University (UNESP), College of Veterinary Medicine and Animal Science, Av. Prof. Doutor Valter Mauricio Correa, CEP 01049010, Botucatu, SP, Brazil; ${ }^{3}$ Ponta Grossa State University (UEPG), Campus Uvaranas, CEP 84030900, Ponta Grossa, PR, Brasil;

${ }^{4}$ Department of Forage Plants and Agrometeorology, Federal University of Rio Grande do Sul, Porto Alegre, RS, Brazil and ${ }^{5}$ Agricultural and Livestock Research Foundation, R. Gonçalves Dias, 570, CEP 90130-060, Porto Alegre, RS, Brazil

\begin{abstract}
The use of forage legumes has been proposed as a means of generating sustainable grazing environments. Their limited use, particularly in tropical pastures, is partially due to the limited knowledge regarding the efficiency of utilization by animals. The present study characterized the sward structure, nutritive value and ingestive behaviour of dairy heifers in pastures of peanut cv. Belmonte under continuous stocking management. Treatments corresponded to sward heights of 5, 10, 15 and $20 \mathrm{~cm}$, according to a randomized complete block design, with four replications. The following response variables were evaluated: vertical distribution of the morphological components within the sward, forage mass, nutritive value (simulated grazing), bite rate (BR), bite mass (BM) and short-term herbage intake rate (STIR). The top half of the sward height was mainly composed of leaves and the bottom half mainly of stolon and dead material regardless of management height. Greater values of neutral detergent fibre and acid detergent fibre were recorded during autumn, while higher values of in-vitro dry matter (DM) digestibility $(0 \cdot 85)$ occurred during spring regardless of management height for the grazed stratum. In relation to treatments, greater values of crude protein were recorded on swards managed at $5 \mathrm{~cm}(0.27)$ and $10 \mathrm{~cm}(0 \cdot 26)$. Bite rate, BM and STIR varied with sward height, but not with a season of the year. The STIR followed a broken line response to sward height, with increasing values up to $13.1 \mathrm{~cm}$ (106 g DM/kg body weight). Sward structure played an important role in determining the STIR. To maximize the STIR of dairy heifers under continuous stocking management, swards should be managed at heights of not $<13.1 \mathrm{~cm}$.
\end{abstract}

\section{Introduction}

The ingestive behaviour of grazing animals has usually been studied on temperate and tropical grasses as a means of establishing management targets that maximize herbage intake and animal performance. This requires an understanding of the grazing process which, in turn, demands characterization of factors interfering with herbage intake and their relationship with sward structural characteristics (the grazing environment), which are important features of the plant-animal interface. The rate of herbage intake is the result of the interaction between bite rate (BR) and bite mass (BM) (Allden \& Whittaker 1970), the latter derived from bite volume (mainly determined by bite depth) and bulk density of the herbage in the grazing horizon (Burlison et al. 1991). This highlights the importance of the sward structure in determining herbage and nutrient intake by grazing animals and indicates the possibility of using swardbased targets to guide management practices (Da Silva \& Carvalho 2005).

Sward structure is normally defined and measured as the distribution and arrangement of above-ground plant parts within a community (Laca \& Lemaire 2000). As descriptors some structural variables are used such as height, herbage bulk density and leaf area index. Several studies with temperate and tropical forage grasses in which the sward structure was evaluated reported a similar pattern of vertical distribution of the morphological components characterized by the predominance of leaves in the top half and of stem and dead material in the bottom half. Such a distribution results in increasing tensile resistance of the morphological components at the bottom strata of the sward, limiting bite depth. Under grazing, herbage intake is increased by the ease of herbage prehension and harvest (Barre et al. 2006), and has a positive relationship with sward height until a maximum intake is reached (Laca et al. 
1992). Underlying this relationship is the bite depth, which appears to be related positively to sward height and constitute a constant proportion of sward height (Griffiths et al. 2003), normally around 0.50 (Laca et al. 1992; Demment et al. 1995; Cangiano et al. 2002; Gonçalves et al. 2009; Gregorini et al. 2009). In this context, height is the structural characteristic of the sward most influential to BM and therefore constitutes important information for identifying management targets that favour high rates of herbage intake necessary to ensure high levels of herbage intake (Hodgson 1990). The majority of studies that relate sward structure to rate of herbage intake, however, have been carried out using temperate and tropical forage grasses.

The use of forage legumes in pastures has been proposed as a means of generating sustainable grazing environments for producing animal products with low cost and environmental impact. The main role of legumes in pastures is to provide nitrogen $(\mathrm{N})$ to forage grasses with the additional benefit of increasing the nutritive value of the consumed herbage. The limited use of forage legumes, particularly in tropical pastures, is partially due to the limited knowledge regarding its utilization by grazing animals, a condition that hampers the establishment of adequate management targets. Among the tropical legumes, the forage peanut (Arachis pintoi Krapovickas \& Gregory cv. Belmonte) stands out as a promising alternative due to the high potential for dry matter (DM) production, nutritive value and persistence (Lascano 1994). However, information regarding the influence of sward structure on the ingestive behaviour of grazing animals is scarce, highlighting the need for studies analogous to those carried out with forage grasses as a means of ensuring its adequate and efficient utilization on pastures. The present study was based on the hypothesis that the pattern of ingestive behaviour of cattle grazing pure stands of forage peanut in relation to variations in sward height is similar to that described for forage grasses, allowing for the identification of management targets for maximizing the shortterm rate of herbage intake.

\section{Materials and methods}

\section{Experimental site}

The experiment was carried out at E.S.A. 'Luiz de Queiroz' (ESALQ), University of São Paulo, Piracicaba, SP, Brazil $\left(22^{\circ} 42^{\prime}\right.$ S, $47^{\circ} 37^{\prime} \mathrm{W}$ and $550 \mathrm{~m}$ a.s.l.), on a forage peanut (A. pintoi Krappovickas \& Gregory cv. Belmonte) stand established on a Eutric Kandiudalf. Average soil chemical characteristics for the $0-20 \mathrm{~cm}$ layer were: $\mathrm{pH}$ calcium chloride $\left(\mathrm{CaCl}_{2}\right): 5 \cdot 85$; organic matter $(\mathrm{OM})=41 \mathrm{dg} / \mathrm{dm}^{3}$; phosphorus $(\mathrm{P}$, ion-exchange resin extraction method $)=77 \mathrm{mg} / \mathrm{dm}^{3}$; calcium $(\mathrm{Ca})=87.5 \mathrm{mmolc} / \mathrm{dm}^{3}$, magnesium $(\mathrm{Mg})=50 \mathrm{mmolc} /$ $\mathrm{dm}^{3} ;$ potassium $(\mathrm{K})=16.3 \mathrm{mmolc} / \mathrm{dm}^{3} ;$ hydrogen + aluminium $(\mathrm{H}+\mathrm{Al})=26.5 \mathrm{mmolc} / \mathrm{dm}^{3}$; sum of bases $=146.3 \mathrm{mmolc} / \mathrm{dm}^{3}$; cation exchange capacity $=172 \cdot 8 \mathrm{mmolc} / \mathrm{dm}^{3}$; base saturation $=84 \%$. These were considered adequate for the forage species used (CEPLAC 2012), with no need for additional fertilization.

The area was planted in November 2011 using stolons and considered established in September 2012, when it was divided into 16 paddocks of approximately $200 \mathrm{~m}^{2}$ each and treatments allocated according to a randomized complete block design, with four replications. Treatments corresponded to four levels of grazing intensity (severe $-S$, moderate - M, lenient $-\mathrm{L}$, and very lenient - VL) represented by the management sward heights of $5,10,15$ and $20 \mathrm{~cm}$ maintained throughout short grazing periods once or twice a week. Sward height was monitored throughout the experimental period twice a week (3 and 4-day intervals) using a sward stick (Barthram 1985). In October, after treatments had been allocated to experimental units, monitoring of sward height was initiated and animals started to be for short grazing periods to maintain management target heights from November 2012 onwards. In January 2013, all paddocks were being maintained at the targeted heights. Paddocks were grazed by dairy heifers (body weight $(B W)=200 \pm 30 \mathrm{~kg}$ ) used only as grazers, and irrigation used as a means of avoiding soil water deficits during the experiment. The experiment was carried out from January to November 2013, and the evaluations were performed in two seasons of the year: autumn (May 20 to June $06,2013)$ and spring (11-22 November 2013). A total of 16 grazing trials was carried out during each season of the year. These lasted for $45+5 \mathrm{~min}$, the minimum necessary for detecting fluctuations in $\mathrm{BW}$ with $10 \mathrm{~g}$ precision on an electronic scale, during the evaluations of the short-term rate of herbage intake (Penning \& Hooper 1985). All grazing sessions were performed either early in the morning or late in the afternoon.

\section{Sward measurements}

During the grazing trials monitoring of sward height was carried out through 90 sward stick readings per paddock (Barthram 1985). Measurements were performed before and after each grazing trial as a means of certifying that differences in sward height at the beginning and end of the trial did not exceed $10 \%$, essential for ensuring that the same sward structure was available throughout the grazing sessions.

Measurements of sward herbage mass and herbage bulk density were carried out by harvesting herbage samples contained within the limits of $0.33 \mathrm{~m}^{2}\left(0.90 \times 0.37 \mathrm{~m}^{2}\right)$ metallic frames. Two samples were harvested per paddock during each season of the year. Samples were cut to ground level and taken to the laboratory for weighing and sub-sampling, before drying in a forced draught oven at $65^{\circ} \mathrm{C}$ until constant weight. Data were used to calculate sward herbage mass $(\mathrm{kg} / \mathrm{DM} / \mathrm{ha})$. Herbage bulk density was calculated by dividing sward herbage mass by the corresponding average sward height, and expressed in $\mathrm{mg} / \mathrm{cm}^{3}$.

The relative proportions and vertical distribution of the morphological and botanical within the vertical profile of the swards were evaluated with an inclined point quadrat (Wilson 1959). The equipment was placed on areas that were representative of sward condition at the time of sampling (visual assessment of sward height and herbage mass). Measurements consisted of the introduction of the graduated stem $(\mathrm{cm})$ throughout the vertical profile of the sward in a $32.5^{\circ}$ angle from the top towards the base. Along the trajectory, as the tip of the stem touched different herbage components, each contact was recorded, specifying the morphological/botanical component touched (leaflet, petiole, stolon, dead material and weeds) and the corresponding reading on the scale. A final reading on the equipment scale was recorded when the tip of the stem reached the ground, which was used as a reference to calculate the real height of the previous contacts. A minimum of 100 contacts was recorded per paddock. Contact heights were recorded sequentially within $2 \mathrm{~cm}$ vertical bands from the ground level.

During the grazing trials, herbage samples $(\sim 200 \mathrm{~g}$ fresh weight) of simulated grazing (de Vries 1995) were harvested for estimating DM content and the botanical/morphological and chemical composition of the grazed stratum. They were taken to 
the laboratory soon after harvest, weighed and separated manually into leaflet, petiole, stolon, dead material and weeds. After separation, all components were dried in a forced draught oven at $65^{\circ} \mathrm{C}$ until constant weight. After drying, samples were ground using a Wiley mill to pass a 1-mm screen for chemical analysis. These were carried out in duplicate for the following components: neutral detergent fibre (NDF) and acid detergent fibre (ADF) according to Van Soest et al. (1991); in-vitro dry matter digestibility (IVDMD) according to Tilley \& Terry (1963) adapted by Van Soest et al. (1991); and crude protein (CP) was determined in a $\mathrm{N}$ analyser (LECO FP-2000 nitrogen analyser, Leco Instruments, Inc., St. Joseph, MI, USA).

\section{Animal measurements}

Measurements of ingestive behaviour were made using three Holstein heifers (10 \pm 1 month-old; $200 \pm 30 \mathrm{~kg} \mathrm{BW})$, two for actual measurements and the third only to ensure minimum group size. The total number of animals used during each grazing trial was defined taking into account the need to maintain relatively stable sward height throughout the measurement period (variation in sward height at the beginning and end of each grazing trial smaller than $10 \%)$. Approximately 10 days before the test, animals were habituated to the experimental procedure and remained on an adjacent pure forage peanut area. They were not subjected to fasting prior to measurements, since it could influence the estimates of herbage intake rate (Greenwood \& Demment 1988) and diet selection (Newman et al. 1994). As a result, all grazing trials were performed early in the morning (06:00-07:00 am) and late in the afternoon (05:00-07:00 pm), i.e. periods of normally intense grazing activity.

The short-term rate of herbage intake was determined using the double weighing technique described by Penning \& Hooper (1985). Before the grazing trials, animals were fitted with faeces and urine collecting bags. After the tests, they were maintained in an adjacent area, with no access to water or feed for $45 \mathrm{~min}$ to estimate metabolic losses (water evaporation and carbonic gas and methane production - insensible weight loss). All weights (pre- and post-grazing, and post-metabolic losses determination) were obtained using an electronic scale with a 10 -g precision level. The short-term rate of herbage intake was calculated using the following equation:

$$
\mathrm{STIR}=d \times\left\{\left[\frac{\left(W_{2}-W_{1}\right)}{\left(t_{2}-t_{1}\right)}\right]+\left[\frac{\left(W_{3}-W_{4}\right)}{\left(t_{4}-t_{3}\right)}\right]\right\} \times\left[\frac{\left(t_{2}-t_{1}\right)}{\mathrm{ET}}\right]
$$

where short-term herbage intake rate (STIR) = short term herbage intake rate; $d=$ dry matter content of herbage (proportion); $W_{1}$ and $W_{2}=$ animal body weight at pre- and post-grazing $(\mathrm{kg}) ; t_{1}$ and $t_{2}=$ pre- and post-grazing time $(\mathrm{min}) ; W_{3}$ and $W_{4}=$ animal body weight at pre- and post-period of insensible weight losses measurement $(\mathrm{kg}) ; t_{3}$ and $t_{4}=$ pre- and post-period of insensible weight losses measurement $(\mathrm{min}) ; \mathrm{ET}=$ effective eating time (min).

Measurements of BR were performed during each grazing trial by a trained observer equipped with a stopwatch and a manual counter. Animals were observed for $10 \mathrm{~min}$ and readings of the time required to take 20 bites were taken for each test animal (Forbes \& Hodgson 1985). Bite mass was calculated by dividing the total amount of DM consumed during the grazing trial by the total number of bites, adjusted for the animals' body weight.

\section{Statistical analysis}

The control variable, i.e. sward height, was considered as a discrete variable. Sward heights of 5, 10, 15 and $20 \mathrm{~cm}$ corresponded to four levels of grazing intensity (severe, moderate, lenient and very lenient). For that reason, data originated from pasture-related measurements were subjected to ANOVA using the MIXED Procedure of SAS ${ }^{\oplus}$ (Statistical Analysis System). The choice of the variance/covariance matrix was made using the Schwarz's Bayesian Criterion (Wolfinger 1993). The model included the fixed effects of sward height, season of the year (autumn and spring) and the interaction between them. Block was considered as a random effect. Treatment means were estimated using the LSMEANS command and comparison, when necessary, made using Student's $t$ test at $P<0.05$. For animal ingestive behaviour data, regression models were run using the Mixed procedure of the same statistical package, with linear $(y i j=a+b x+E i j)$, quadratic $\left(y i j=a+b x+c x^{2}+E i j\right)$ and segmented (broken line, $y i j=L$ $+U[(x<R)(x-R)]+E i j)$ models, where: ' $y i j$ ' is the dependent variable, ' $a$ ' is the intercept, ' $b$ ' the linear coefficient, ' $c$ ' is the quadratic coefficient, ' $x$ ' is the independent variable (actual sward height), ' $L$ ' is the maximum observed value, ' $U$ ' is a constant of the equation, ' $R$ ' is the break point and 'Eij' represent the experiment error. When more than one model was significant $(P<0.05)$, the equation with the highest coefficient of determination $\left(R^{2}\right)$ was chosen. The effect of season of the year (autumn and spring) was included in the regression equations to detect if the behaviour responses in relation to actual sward height differed between seasons at $P<0.05$.

\section{Results}

The variation in sward height during the grazing trials throughout the experimental period was smaller than the planned $10 \%$ limit (Table 1$)$. Herbage mass $(\mathrm{HM})$ varied with treatment $(P<0.001)$ and season of the year $(P=0.003)$, and the interaction was significant $(P=0.005)$. Sward herbage mass increased as management height increased during autumn and spring. There was no difference between seasons of the year for swards managed at 5 and $10 \mathrm{~cm}$, with greater HM values recorded during autumn relative to spring on those managed at 15 and $20 \mathrm{~cm}$. Herbage bulk density $(\mathrm{BD})$ varied with sward height $(P=0.003)$ and sward height $\times$ season of the year interaction $(P=0.005)$. During autumn, there was no difference in $\mathrm{BD}$ among treatments. On the other hand, during spring, $\mathrm{BD}$ decreased as management height increased, with similar values recorded for swards managed at 15 and $20 \mathrm{~cm}$. Differences between seasons of the year were seen only for swards managed at $15 \mathrm{~cm}$, with greater values recorded during autumn relative to spring (Table 1).

During autumn and spring, the top half of the sward height was mainly composed of leaves (leaflets and petioles) and the bottom half composed mainly of stolon and dead material regardless of management height, with a greater proportion of weeds on swards managed at 15 and $20 \mathrm{~cm}$ (Figs 1 and 2).

The botanical and morphological composition of simulated grazing herbage samples did not vary with sward height or season of the year (Table 2), except for dead material, for which greater values were recorded during autumn relative to spring (0.091 and $0 \cdot 044 \pm 0 \cdot 0118$, respectively). The herbage consumed was composed mainly of leaves (leaflets and petioles).

The chemical composition of the simulated grazing herbage samples varied with a season of the year for all the chemical traits 
Table 1. Sward height at pre- and post-grazing trial, sward herbage mass and herbage bulk density of Arachis pintoi cv. Belmonte subjected to intensities of grazing (means; $\mathrm{n}=16$ ) during autumn and spring 2013

\begin{tabular}{|c|c|c|c|c|c|c|c|c|c|}
\hline \multirow[b]{2}{*}{ Variable } & \multirow[b]{2}{*}{ Sward height (cm) } & \multicolumn{2}{|c|}{ Season of the year } & \multicolumn{3}{|c|}{ S.E.M. } & \multicolumn{3}{|c|}{$P$-value } \\
\hline & & Autumn & Spring & $\mathrm{T}$ & $\mathrm{S}$ & $\mathrm{T} \times \mathrm{S}$ & $\mathrm{T}$ & $\mathrm{S}$ & $\mathrm{T} \times \mathrm{S}$ \\
\hline \multirow[t]{4}{*}{ Sward height pre-trial $(\mathrm{cm})$} & 5 & $5 \cdot 4$ & $6 \cdot 1$ & 0.22 & 0.22 & 0.41 & NA & NA & NA \\
\hline & 10 & $10 \cdot 1$ & $9 \cdot 8$ & & & & & & \\
\hline & 15 & $14 \cdot 3$ & $16 \cdot 0$ & & & & & & \\
\hline & 20 & $18 \cdot 2$ & $20 \cdot 8$ & & & & & & \\
\hline \multirow[t]{4}{*}{ Sward height post-trial $(\mathrm{cm})$} & 5 & $5 \cdot 2$ & $5 \cdot 8$ & 0.33 & $0 \cdot 31$ & 0.53 & NA & NA & NA \\
\hline & 10 & $9 \cdot 5$ & $9 \cdot 0$ & & & & & & \\
\hline & 15 & $13 \cdot 8$ & $15 \cdot 1$ & & & & & & \\
\hline & 20 & $18 \cdot 0$ & $19 \cdot 7$ & & & & & & \\
\hline \multirow[t]{4}{*}{ Herbage mass (kg/ha) } & 5 & 4540 & 4910 & $547 \cdot 5$ & $386 \cdot 8$ & $813 \cdot 4$ & $<0.0001$ & 0.0032 & 0.0049 \\
\hline & 10 & 7340 & 7760 & & & & & & \\
\hline & 15 & 12550 & 8610 & & & & & & \\
\hline & 20 & 16130 & 11980 & & & & & & \\
\hline \multirow[t]{4}{*}{ Herbage bulk density $\left(\mathrm{mg} / \mathrm{cm}^{3}\right)$} & 5 & $9 \cdot 1$ & $9 \cdot 8$ & 0.54 & $0 \cdot 39$ & $0 \cdot 70$ & 0.0028 & 0.0863 & 0.0344 \\
\hline & 10 & $7 \cdot 3$ & $7 \cdot 8$ & & & & & & \\
\hline & 15 & $8 \cdot 4$ & $5 \cdot 7$ & & & & & & \\
\hline & 20 & $8 \cdot 1$ & $6 \cdot 3$ & & & & & & \\
\hline
\end{tabular}

S.E.M., standard error of the mean; P-value, significance level; T, treatment; $S$, season of the year; NA, not analysed (control variable).

studied (Table 3). Greater values of NDF and ADF were recorded during autumn. On the other hand, greater values of IVDMD and $\mathrm{CP}$ were recorded during spring. In relation to treatment, greater values of CP were recorded on swards managed at 5 and $10 \mathrm{~cm}$ relative to those managed at 15 and $20 \mathrm{~cm}$.

Bite rate, $\mathrm{BM}$ and herbage intake rate varied with sward height $(P<0.001$ for all variables), but not with a season of the year. Bite rate showed a negative linear relationship with sward height (Fig. 3), while BM showed a positive linear relationship (Fig. 4). The rate of intake followed a broken line response to sward height, with increasing values up to $13.1 \mathrm{~cm}$, when a maximum value was achieved $(0.106 \mathrm{~g} \mathrm{DM} \mathrm{kg} / \mathrm{BW} / \mathrm{min})$ and no further increase was observed (Fig. 5).
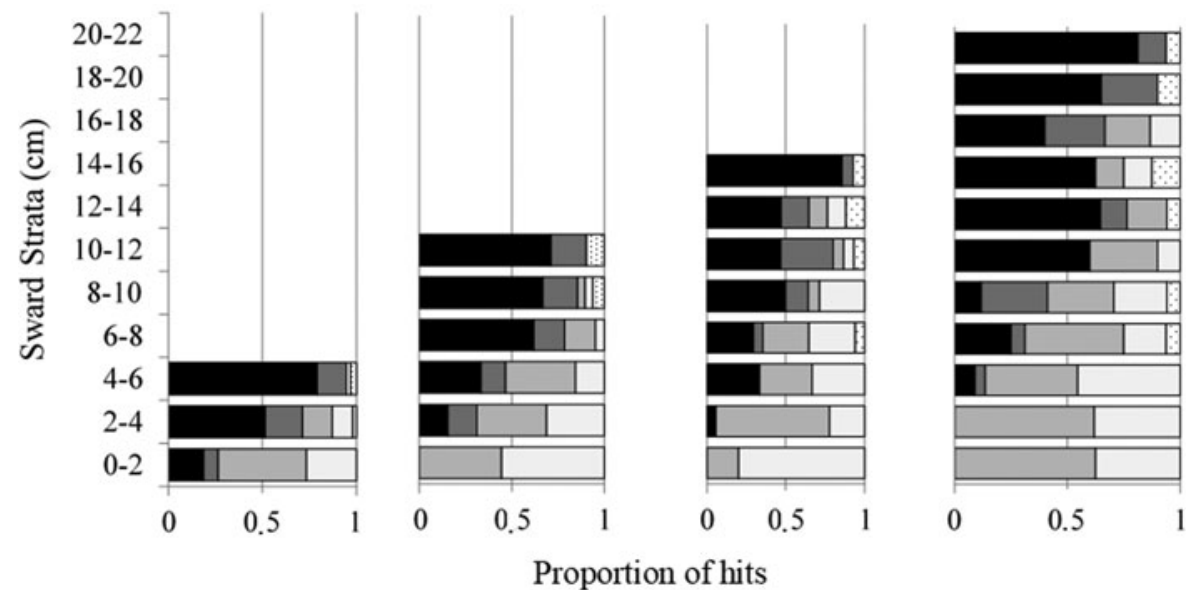

\section{Discussion}

Control of sward structure was achieved efficiently during autumn and spring, as demonstrated by the actual values of management height of the paddocks before and after each grazing trial. The difference in sward heights pre- and post-trials was smaller than the stipulated $10 \%$ limit, indicating that the same sward structure was available throughout the grazing sessions. Herbage bulk density did not vary with management height during autumn, but decreased with the increase in sward height during spring, probably a consequence of the greater height recorded for treatments 15 and $20 \mathrm{~cm}$ during spring relative to autumn. Additionally, the proportion of dead material in sward herbage mass was greater during autumn, causing herbage bulk density to be greater during

Proportion of hits
Fig. 1. Vertical distribution of the botanical/morphological components of sward at 2-cm strata from ground level of Arachis pintoi cv. Belmonte subjected to intensities of grazing during autumn 2013. Leaflets $\square$, petioles $(\square$, stolon $(\square)$, dead material $(\square)$, weeds $(\square)$. 
Fig. 2. Vertical distribution of the botanical/morphological components of sward herbage mass at $2-\mathrm{cm}$ strata from ground level of Arachis pintoi cv. Belmonte subjected to intensities of grazing during spring 2013. Leaflets $(\square$, petioles $(\square$, stolon $\square$, dead material $(\square)$, weeds $\square$.
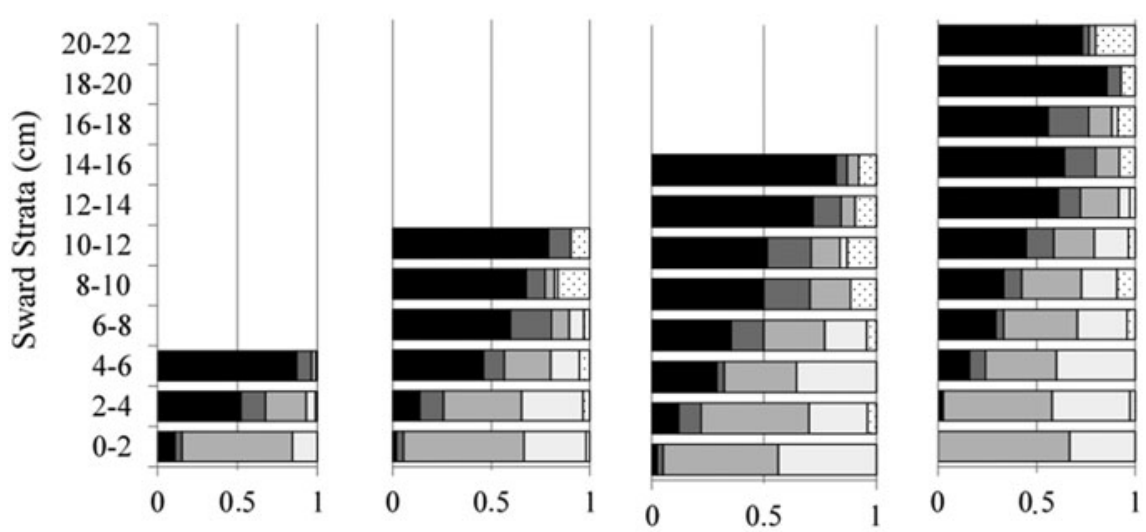

Proportion of hits autumn relative to spring. Recorded values varied from $9 \cdot 8$ to $6.3 \mathrm{mg} / \mathrm{cm}^{3}$ for swards managed at 5 and $20 \mathrm{~cm}$, respectively. The pattern of variation in bulk density relative to sward height in spring was similar to that described for temperate (Hodgson 1990; Brink \& Soder 2011) and tropical climate (Stobbs 1973; Sollenberger \& Burns 2001; Fonseca et al. 2012) forage grasses. The high values obtained for bulk density are probably a consequence of the growth habit (stoloniferous) and leaf architecture (horizontal) of the forage peanut cv. Belmonte. For white clover (Trifolium repens cv. Rivendel), a temperate forage legume of similar growth habit to forage peanut, reported values of herbage bulk density vary from 8.9 to $11.8 \mathrm{mg} / \mathrm{cm}^{3}$ for swards managed at 12 and $26 \mathrm{~cm}$, respectively (Combes et al. 2011). For the stoloniferous tropical grass Tifton 85 subjected to an experimental protocol analogous to the one used in the present study, herbage bulk density values corresponded to $6.1,4.8,4.2$ and $3.7 \mathrm{mg} / \mathrm{cm}$ for the management heights of $5,10,15$ and $20 \mathrm{~cm}$, respectively (Carnevalli et al. 2001).

Information about the nutritive value of the consumed herbage (simulated grazing samples) allows inferences about potential nutrient intake from morphological/botanical composition and short-term rate of herbage intake data. The higher nutritive value of the herbage during spring was a consequence of the smaller proportion of dead material on the top strata of the swards relative to autumn $(0.044$ and $0.091 \pm 0.0118$, respectively). Swards managed at 5 and $10 \mathrm{~cm}$ resulted in herbage with greater $\mathrm{CP}$ percentage and higher IVDMD, possibly due to the younger tissues comprising the sward herbage mass. Under more intense defoliation (5 and $10 \mathrm{~cm}$ management height), the frequency of defoliation (Sollenberger \& Vanzant 2011) and consequently the turnover of leaves and stolons is greater than under more lenient defoliation (15 and $20 \mathrm{~cm}$ management height), resulting in younger plants and greater proportion of leaf in sward herbage mass. Nevertheless, it is worth noting that the variation in chemical composition detected was within limits that did not hamper herbage intake or animal performance (Reid 1994; Noller 1997), supporting the importance of sward structure as a determinant of the ingestive behaviour and nutrient intake of grazing animals. In this context, management and knowledge of sward height is key for controlling morphological composition and thus potential intake and animal performance. Nutritive value is not necessarily related to intake (Boval et al. 2014).

The general pattern of morphological component distribution along the vertical profile of the swards was consistent during autumn and spring. Regardless of sward height, leaves (leaflets + petioles) were the predominant component in the top half, and stolons and dead material the predominant components in the bottom half of swards. This proportionality in vertical distribution of morphological components in sward herbage mass was originally described for temperate forage grasses (Wilson 1959; Brink \& Soder 2011) and subsequently verified for tropical forage grasses (Stobbs 1973; Fonseca et al. 2013; Lemos et al. 2014), indicating the existence of a common and consistent pattern of sward structure for different forage species and plant growth habits.

The constant proportion of the sward height consisting mainly of leaves (top 0.50) indicates an increase of the potential grazing stratum (bite depth) for taller management heights, a BM determining characteristic and, consequently, very influential on the

Table 2. Proportion of leaflet, petiole, stolon, dead material and weeds in simulated grazing herbage samples of Arachis pintoi cv. Belmonte subjected to intensities of grazing during autumn and spring 2013

\begin{tabular}{|c|c|c|c|c|c|c|c|c|c|c|c|c|}
\hline \multirow[b]{2}{*}{ Variable } & \multicolumn{4}{|c|}{ Sward height $(\mathrm{cm})$} & \multicolumn{2}{|c|}{ Season of the year } & \multicolumn{3}{|c|}{ S.E.M. } & \multicolumn{3}{|c|}{$P$-value } \\
\hline & 5 & 10 & 15 & 20 & Autumn & Spring & $\mathrm{T}$ & $\mathrm{S}$ & $\mathrm{T} \times \mathrm{S}$ & $\mathrm{T}$ & $\mathrm{S}$ & $\mathrm{T} \times \mathrm{S}$ \\
\hline Leaflet & 0.67 & 0.71 & 0.59 & 0.60 & 0.63 & 0.69 & 0.050 & 0.047 & 0.095 & 0.415 & 0.068 & 0.438 \\
\hline Petiole & $0 \cdot 20$ & $0 \cdot 11$ & 0.11 & $0 \cdot 11$ & $0 \cdot 10$ & $0 \cdot 12$ & 0.046 & 0.033 & 0.065 & 0.895 & 0.070 & 0.460 \\
\hline Stolon & 0.03 & 0.02 & 0.08 & $0 \cdot 10$ & 0.07 & 0.05 & 0.020 & 0.020 & 0.040 & 0.092 & $0 \cdot 207$ & 0.351 \\
\hline Dead material & 0.08 & 0.06 & 0.07 & 0.05 & 0.09 & 0.04 & 0.013 & 0.012 & 0.024 & 0.549 & 0.005 & $0 \cdot 116$ \\
\hline Weeds & 0.02 & $0 \cdot 10$ & 0.15 & 0.14 & $0 \cdot 11$ & $0 \cdot 10$ & 0.040 & 0.031 & 0.053 & $0 \cdot 1188$ & 0.926 & 0.561 \\
\hline
\end{tabular}

S.E.M., standard error; $P$-value, significance level; T, treatment; S, season of the year. 
Table 3. Composition (g/kg DM) and in vitro dry mater digestibility (IVDMD) of simulated grazing herbage samples of Arachis pintoi cv. Belmonte subjected to intensities of grazing during autumn and spring 2013

\begin{tabular}{|c|c|c|c|c|c|c|c|c|c|c|c|c|}
\hline \multirow[b]{2}{*}{ Item } & \multicolumn{4}{|c|}{ Sward height $(\mathrm{cm})$} & \multicolumn{2}{|c|}{ Season } & \multicolumn{3}{|c|}{ S.E.M. } & \multicolumn{3}{|c|}{$P$-value } \\
\hline & 5 & 10 & 15 & 20 & Autumn & Spring & $\mathrm{T}$ & $S$ & $\mathrm{~T} \times \mathrm{S}$ & $T$ & $S$ & $\mathrm{~T} \times \mathrm{S}$ \\
\hline NDF & 321 & 326 & 339 & 322 & 355 & 298 & $9 \cdot 1$ & $5 \cdot 6$ & $7 \cdot 8$ & 0.147 & $<0.001$ & 0.277 \\
\hline ADF & 209 & 221 & 223 & 219 & 238 & 197 & $5 \cdot 7$ & $3 \cdot 7$ & $4 \cdot 8$ & 0.087 & $<0.001$ & 0.183 \\
\hline IVDMD & 0.82 & 0.83 & 0.82 & 0.82 & 0.80 & 0.85 & 0.47 & $0 \cdot 31$ & 0.36 & 0.001 & 0.010 & 0.748 \\
\hline $\mathrm{CP}$ & 270 & 258 & 231 & 230 & 238 & 257 & $7 \cdot 1$ & $5 \cdot 0$ & $6 \cdot 2$ & 0.735 & $<0.001$ & 0.499 \\
\hline
\end{tabular}

S.E.M., standard error of the mean; NDF, neutral detergent fibre; ADF, acid detergent fibre; IVDMD, in vitro dry matter digestibility; CP, crude protein.

short-term rate of herbage intake (Barrett et al. 2001). According to Brink \& Soder (2011), the predominance of leaves in the top half of sward height is the most important sward characteristic related to herbage intake, since leaves are the morphological component with the least shearing strength for bite prehension relative to other plant components (Flores et al. 1993). Bite mass, defined as the amount of herbage harvested per bite, is determined by the depth the animal's mouth reaches into the sward and with the bulk density of the herbage in the stratum being explored (Gordon \& Lascano 1993). As a result, it has a positive linear relationship with sward height (Hodgson et al. 1994). Research with forage grasses has demonstrated that bite depth corresponds to a constant proportion equivalent to 0.50 of sward height (Laca et al. 1992; Cangiano et al. 2002; Gonçalves et al. 2009; Gregorini et al. 2009), which is in agreement with the increase in BM with increasing sward height seen in the present study. On swards managed at 15 and $20 \mathrm{~cm}, \mathrm{BM}$ was almost three times greater than on swards managed at $5 \mathrm{~cm}(1.57 v$. $4.61 \mathrm{mg} \mathrm{DM} / \mathrm{kg} \mathrm{BW})$. The results have similar magnitude to those reported by Fonseca et al. (2013) for forage sorghum (Sorghum bicolour) managed at 30, 40, 50, 60, 70 and $80 \mathrm{~cm}$, when the maximum rate of herbage intake was recorded for the $50-\mathrm{cm}$ management height and corresponded to $4.55 \mathrm{mg} \mathrm{DM} /$ $\mathrm{kg}$ BW. For Cynodon sp. managed at 10, 15, 20, 25, 30 and $35 \mathrm{~cm}, \mathrm{BM}$ varied from 1.90 to $3.90 \mathrm{mg} \mathrm{DM} / \mathrm{kg} \mathrm{BW}$, with the greatest values recorded on swards managed at $20 \mathrm{~cm}$ (Mezzalira et al. 2014). Such a pattern of response was also reported by Soder et al. (2009) in a study on sward structure

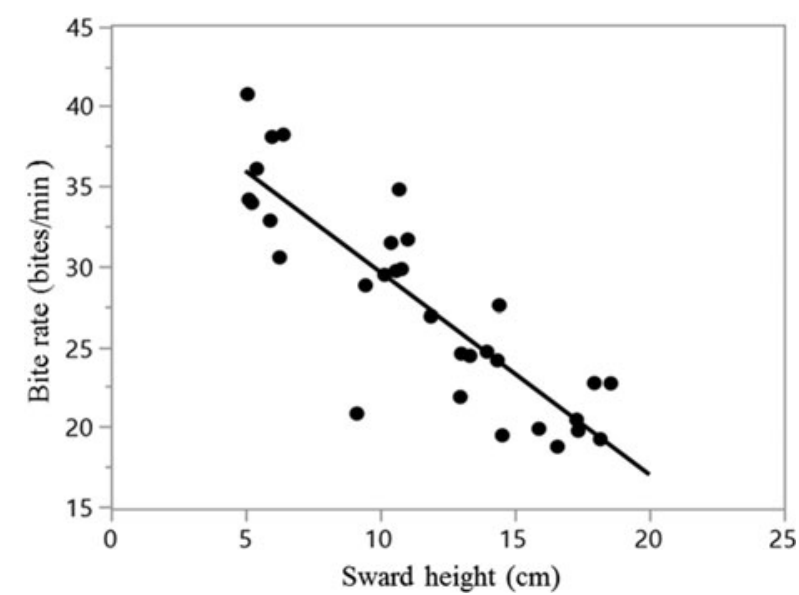

Fig. 3. Bite rate of cattle grazing Arachis pintoi cv. Belmonte $(y=42 \cdot 25-1 \cdot 26 x$; $R^{2}=0.75 ;$ S.D. $=3.26 ; P<0.001 ; n=32$ ) during autumn and spring 2013. and its influence on BM using four forage grasses (Dactylis glomerata, Elymus repens, Schedonorus pratensis and Phalaris arundinacea) during two consecutive years. Those authors reported greater sward heights in the first year relative to the second year for the different species $(25.7 v .17 .0 \mathrm{~cm})$, a condition that was associated with the greater BM (1.05 v. $0.50 \mathrm{~g}$ DM, respectively). Their conclusion was that differences in sward height during the 2 years were more important than differences in plant species for determining BM.

Variations in BM are normally compensated by variations in BR, a condition that generates a relatively stable rate of herbage intake within a range of sward management heights (Hodgson 1990). Bite rate decreased linearly as sward height increased, an inverse pattern to that described for BM, ratifying the inverse relationship between these two response-variables and suggestive of a compensation mechanism as a means of maximizing herbage intake rate when $\mathrm{BM}$ varies in response to particular characteristics of the grazing environment. A similar response pattern was also described by Gibb et al. (1999) for perennial ryegrass (Lolium perenne L. Cv. Melle), which was characterized by an increase in jaw movements (75.3-80.3 movements/min) as sward management height decreased $(9,7$ and $5 \mathrm{~cm})$. The increase in jaw movements, however, did not compensate the smaller BM, resulting in a linear decrease of the herbage intake rate as sward management height decreased (24.6-18.9 g DM/min).

The intake rate of herbage usually increases with increasing sward management height or herbage mass until reaching a maximum value (plateau) defined by some limitation of the animals'

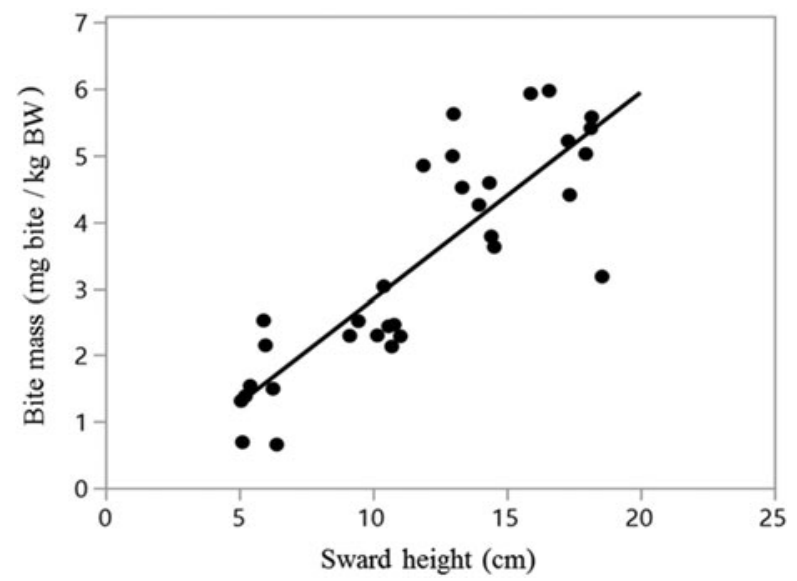

Fig. 4. Bite mass of cattle grazing Arachis pintoi cv. Belmonte expressing in $\mathrm{mg}$ bite per kg body weight (BW) $\left(y=-0.28+0.31 x ; R^{2}=0.73 ;\right.$ s.D. $\left.=0.86 ; P<0.001 ; n=32\right)$ during autumn and spring 2013. 


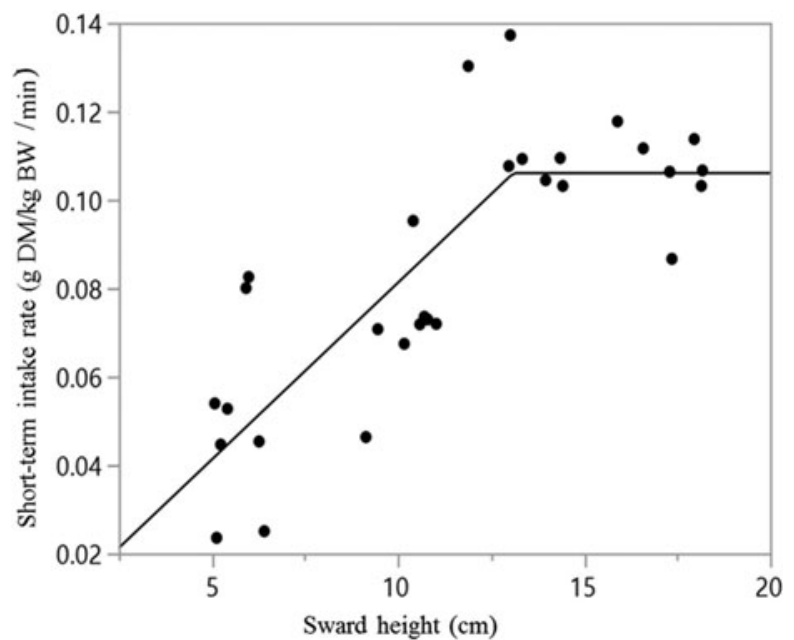

Fig. 5. Short-term rate of herbage intake of cattle grazing Arachis pintoi cv. Belmonte $\left(y=0.0012+0.008 x\right.$, if $x<13.1 ;$ and $y=0.106$, if $\left.x>13.1 ; R^{2}=0.68 ; P<0.001 ; n=30\right)$ during autumn and spring 2013.

ability to process the harvested herbage (Gordon \& Illius 1992). As described for forage grasses, the rate of herbage intake of forage peanut cv. Belmonte increased with increasing sward management height during both autumn and spring, reaching a maximum value at a management height equivalent to $13.1 \mathrm{~cm}$ (106.0 $\mathrm{mg} \mathrm{DM} / \mathrm{kg} \mathrm{BW} / \mathrm{min})$. On swards managed at 5 and $10 \mathrm{~cm}$, the smaller BM was associated with greater BRs, but smaller rates of herbage intake. In this case, the increase in BR was not big enough to compensate the reduction in BM, and rate of intake decreased linearly. The rate of herbage intake was $147 \%$ greater on swards managed at 15 and $20 \mathrm{~cm}$ relative to those managed at $5 \mathrm{~cm}$. On the other hand, the 15 and $20 \mathrm{~cm}$ management heights resulted in greater $\mathrm{BM}$, but with no difference in intake rate between the two management heights, probably a consequence of the longer period necessary for completion of each bite (e.g. smaller BR). That is suggestive of a stabilization in the rate of herbage intake of $A$. pintoi $\mathrm{cv}$. Belmonte at sward management heights taller than $13.1 \mathrm{~cm}$.

Sward structure played an important role in determining the short-term rate of herbage intake of the grazing animals, highlighting the importance of its knowledge and understanding for ensuring a favourable grazing environment characterized by high rates of herbage intake for forage peanut cv. Belmonte, similar to what is already known for temperate and tropical forage grasses (Carvalho 2005). Variations in sward structure result in changes in BM that, in turn, result in changes in $\mathrm{BR}$ as a means of maximizing the rate of herbage intake. Sward management height is an effective way of managing sward structure and, for forage peanut $\mathrm{cv}$. Belmonte, such compensation mechanism operates in sward management heights taller than $13.1 \mathrm{~cm}$.

\section{Conclusion}

For maximizing the short-term rate of herbage intake of dairy heifers under continuous stocking management, swards should be managed at swards heights not $<13.1 \mathrm{~cm}$. The chemical composition of the simulated grazing samples demonstrated that within the range of management heights studied, herbage nutritive value was not limiting for a wide range of animal species and categories, confirming the importance of sward structure as a determinant of herbage and nutrient intake by grazing animals and appropriate means for defining management targets. Another interesting finding is that there are more similarities than differences between forage grasses and $A$. pinto $i \mathrm{cv}$. Belmonte regarding variations in ingestive behaviour relative to changes in sward structure, highlighting the potential and applicability of the variable sward height as a management tool for monitoring, controlling and executing grazing management.

\section{References}

Allden WG and Whittaker IAM (1970) The determinants of herbage intake by grazing sheep: the interrelationship o factors influencing herbage intake and availability. Australian Journal of Agricultural Research 21, 755-766.

Barre P, Emile JC, Betin M, Surault F, Ghesquière M and Hazard L (2006) Morphological characteristics of perennial ryegrass leaves that influence short-term intake in dairy cows. Agronomy Journal 98, 978-985.

Barrett PD, Laidlaw AS, Mayne CS and Christie H (2001) Pattern of herbage intake rate and bite dimensions of rotationally grazed dairy cows as sward height declines. Grass and Forage Science 56, 362-373.

Barthram GT (1985) Experimental techniques: the HFRO sward stick. In Barthram GT (ed.). The Hill Farming Research Organization Biennial Report 1984/1985. Penicuik, UK: HFRO, pp. 29-30.

Boval M, Coppry O and Sauvant D (2014) Mechanistic model of intake of tropical pasture, depending on the growth and morphology of forage at a vegetative stage. Animal Production Science 54, 2097-2104.

Brink GE and Soder KJ (2011) Relationship between herbage intake and sward structure of grazed temperate grasses. Crop Science 51, 2289-2298.

Burlison AJ, Hodgson J and Illius AW (1991) Sward canopy structure and the bite dimensions and bite weight of grazing sheep. Grass and Forage Science 46, 29-38.

Cangiano CA, Galli JR, Pece MA, Dichio L and Rozsypalek SH (2002) Effect of liveweight and pasture height on cattle bite dimensions during progressive defoliation. Australian Journal of Agricultural Research 53, 541-549.

Carnevalli RA, Da Silva SC, Fagundes JL, Sbrissia AF, de Carvalho CAB, Pinto LFM and Pedreira CGS (2001) Desempenho de ovinos e respostas de pastagens de tifton 85 (Cynodon spp.) sob lotação contínua. Scientia Agricola 58, 7-15.

Carvalho PCF (2005) O manejo da pastagem como gerador de ambientes pastoris adequados à produção animal. In Pedreira CGS, Moura JC, Silva SC and Faria VP (eds). Teoria e Prática da Produção Animal em Pastagens. Piracicaba, SP, Brasil: FEALQ, pp. 7-32.

CEPLAC (2012) Leguminosas - Amendoim Forrageiro. Itabuna, Bahia, Brazil: Comissão Executiva do Plano da Lavoura Cacaueira. Available at http:// www.ceplac.gov.br/radar/amendoim\%20forrageiro.htm (Accessed 9 November 2017).

Combes D, Decau ML, Rakocevic M, Jacquet A, Simon JC, Sinoquet H, Sonohat G and Varlet-Grancher C (2011) Simulating the grazing of a white clover 3-D virtual sward canopy and the balance between bite mass and light capture by the residual sward. Annals of Botany 108, 1203-1212.

Da Silva SC and Carvalho PCF (2005) Foraging behaviour and herbage intake in the favourable tropics/sub-tropics. In McGilloway DA (ed.). Grassland: A Global Resource. Wageningen, The Netherlands: Wageningen Academic Publ, pp. 81-95.

Demment MW, Peyraud JL and Laca EA (1995) Herbage intake at grazing: a modelling approach. In Journet $\mathrm{M}$, Grenet $\mathrm{E}$, Farce $\mathrm{MH}$, Thèriez $\mathrm{M}$ and Demarquilly C (eds). Recent Devlopment Nutrition of Herbivory. Paris, France: INRA Editions, pp. 121-141.

de Vries MFW (1995) Estimating forage intake and quality in grazing cattle: a reconsideration of the hand-plucking method. Journal of Range Management 48, 370-375.

Flores ER, Laca EA, Griggs TC and Demment MW (1993) Sward height and vertical morphological differentiation determine cattle bite dimensions. Agronomy Journal 85, 527-532.

Fonseca L, Mezzalira JC, Bremm C, Filho RSA, Gonda HL and Carvalho PCF (2012) Management targets for maximising the short-term herbage intake rate of cattle grazing in Sorghum bicolor. Livestock Science 145, 205-211. 
Fonseca L, Carvalho PCF, Mezzalira JC, Bremm C, Galli JR and Gregorini P (2013) Effect of sward surface height and level of herbage depletion on bite features of cattle grazing Sorghum bicolor swards. Journal of Animal Science 91, 4357-4365.

Forbes TDA and Hodgson J (1985) Comparative studies of the influence of sward conditions on the ingestive behaviour of cows and sheep. Grass and Forage Science 40, 69-77.

Gibb MJ, Huckle CA, Nuthall R and Rook AJ (1999) The effect of physiological state (lactating or dry and sward surface height on grazing behaviour and intake by dairy cows. Applied Animal Behaviour Science 63, 269-287.

Gonçalves EN, Carvalho PCF, Kunrath TR, Carassai IJ, Bremm C and Fischer V (2009) Relações planta-animal em ambiente pastoril heterogêneo: processo de ingestão de forragem. Revista Brasileira de Zootecnia 38, 1655-1662.

Gordon LI and Illius AW (1992) Foraging strategy: from monoculture to mosaics. In Speedy AW (ed.). Progress in Sheep and Goat Research. Wallingford, UK: CAB International, pp. 153-178.

Gordon IJ and Lascano C (1993) Foraging strategies of ruminant livestock on intensively managed grasslands: potentials and constraints. In Baker MJ, Crush JR and Humphrey LR (eds). Proceedings of the 17th International Grassland Congress. Hamilton, New Zealand: International Grassland Congress, pp. 681-389.

Greenwood GB and Demment MW (1988) The effect of fasting on shortterm cattle grazing behaviour. Grass and Forage Science 43, 377-386.

Gregorini P, Gunter SA, Beck PA, Caldwell J, Bowman MT and Coblentz WK (2009) Short-term foraging dynamics of cattle grazing swards with different canopy structures. Journal of Animal Science 87, 3817-3824.

Griffiths WM, Hodgson J and Arnold GC (2003) The influence of sward canopy structure on foraging decisions by grazing cattle. I. Patch selection. Grass and Forage Science 58, 112-124.

Hodgson J, Clark DA and Mitchell RJ (1994) Foraging behaviour in grazing animals and its impact on plant communities. In Fahey GC (ed.). Forage Quality, Evaluation and Utilization. Madison, WI, USA: ASA, CSSA, SSSA, pp. 796-827.

Hodgson JG (1990) Grazing Management: Science into Practice. New York, NY, USA: John Wiley Longman Scientific and Technical.

Laca EA and Lemaire G (2000) Measuring sward structure. In ' $t$ Mannetje L and Jones RM (eds). Field and Laboratory Methods for Grassland and Animal Production Research. New York, USA: Cabi, pp. 103-122.

Laca EA, Ungar ED, Seligman N and Demment MW (1992) Effects of sward height and bulk density on bite dimensions of cattle grazing homogeneous swards. Grass and Forage Science 47, 91-102.

Lascano CE (1994) Nutritive value and animal production of forage Arachis. In Kerridge PC and Hardy B (eds). Biology and Agronomy of Forage Arachis. Colombia, Cali: CIAT, pp. 109-121.
Lemos NLS, Ruggieri AC, Silva CV, Campos AF, Malheiros EB and Teixeira IAMA (2014) Tanzania grass structure grazed by goats managed with different residual leaf area index under intermittent stocking. Bioscience Journal 30, 1811-1818.

Mezzalira JC, Carvalho PCF, Fonseca L, Bremm C, Cangiano C, Gonda HL and Laca EA (2014) Behavioural mechanisms of intake rate by heifers grazing swards of contrasting structures. Applied Animal Behaviour Science 153, $1-9$.

Newman JA, Penning PD, Parsons AJ, Harvey A and Orr RJ (1994) Fasting affects intake behaviour and diet preference by grazing sheep. Animal Behaviour 47, 185-193.

Noller CH (1997) Nutritional requirements of grazing animals. In Gomide JA (ed.). Simpósio Internacional sobre produção Animal em Pastejo (International Symposium on Animal Production under Grazing). Viçosa, MG, Brazil: Federal University of Viçosa, pp. 145-172.

Penning P and Hooper GE (1985) An evaluation of the use of short term weight changes in grazing sheep for estimating herbage intake. Grass and Forage Science 40, 79-84.

Reid RL (1994) Milestones in forage research (1969-1994). In Fahey GC, Collins MJR, Mertens DR and Moser LE (eds). Forage Quality, Evaluation ad Utilization. Madison, WI, USA: ASA, CSSA and SSSA, pp. $1-58$.

Soder KJ, Sanderson MA, Gregorini P, Orr RJ, Rubano MD and Rook AJ (2009) Relationship of bite mass of cattle to sward structure of four temperate grasses in short-term grazing sessions. Grass and Forage Science 64, 421-431.

Sollenberger LE and Burns JC (2001) Canopy characteristics, ingestive behaviour and herbage intake in cultivated tropical grasslands. In Gomide JA (ed.). Proceedings of the 19th International Grassland Congress. Sao Paulo, Brazil: Fundacao de Estudos Agrarios Luiz de Queiroz, pp. 321-327.

Sollenberger LE and Vanzant ES (2011) Interrelationships among forage nutritive value and quantity and individual animal performance. Crop Science 51, 420-432.

Stobbs TH (1973) The effect of plant structure on the intake of tropical pastures. I. Variation in the bite size of grazing cattle. Australian Journal of Agricultural Research 24, 809-819.

Tilley JMA and Terry RA (1963) A two-stage technique for the in vitro digestion of forage crops. Grass and Forage Science 18, 104-111.

Van Soest PJ, Robertson JB and Lewis BA (1991) Methods for dietary fiber, neutral detergent fiber, and nonstarch polysaccharides in relation to animal nutrition. Journal of Dairy Science 74, 3583-3597.

Wilson JW (1959) Analysis of the spatial distribution of foliage by twodimensional point quadrats. New Phytologist 58, 92-99.

Wolfinger R (1993) Covariance structure selection in general mixed models. Communications in Statistics - Simulation and Computation 22, 1079-1106. 